\title{
The Channel of Demand in the Fight against Food Insecurity in the Northern Regions of Cameroon: A Retrospective Analysis
}

\author{
Alim Belek ${ }^{1}$ \\ ${ }^{1}$ Faculty of Economics and Management, University of Dschang, Cameroon \\ Correspondence: Alim Belek, Faculty of Economics and Management, University of Dschang, BP 110, \\ Dschang-Cameroon. Tel: 237-7769-2710/237-7750-6265. E-mail: alim.belek@yahoo.fr
}

Received: July 25, 2012 Accepted: August 24, 2012 Online Published: October 23, 2012

doi:10.5539/ijbm.v7n21p131 URL: http://dx.doi.org/10.5539/ijbm.v7n21p131

\begin{abstract}
The income elasticity of food expenditures versus income elasticity of calories intake controversy marked all the literatures of the 1980 and 1990 decennaries at the subject of fight against foods insecurity.

Food insecurity phenomena are recurrent in northern Cameroon.

Public policies for ameliorating the level of nutrition of undernourished and vulnerable households consisted to distribution cereals. Without any theoretical and empirical basis, all redistribution policies are budgetary costly and can generate unwished or negative effects and be with limited impact.

The aim of this study is to situate the Cameroonian specificities in the income elasticity controversy and to propose the optimal canal of transmission of policies effects. The utilization of raw data of ECAM96 in a retrospective study place income elasticity of food expenditures at the interval $[0.21,1.54]$ and income elasticity of calories intake in $[0.39,0.59]$ for households.

The income elasticity of food expenditures channel is optimal. The increase of real income however have to be oriented on food prices for exclusive consumption of target households for to channel policy effects and to avoid negative effects on social sectors (health, education).
\end{abstract}

Keywords: food insecurity, households, income elasticity, food expenditures, calories intake, social sector

\section{Introduction}

The early nineties were marked by the rise of the phenomenon of food insecurity in the northern regions of Cameroun. This phenomenon was explained for a long time by the low harvests of food products. Government policies were geared towards the improvement of the conditions of supply, particularly production. The mid nineties however marked a change in the approach of the phenomenon of food insecurity. The policies were then directed towards the channel of demand, particularly through the instrument of food subsidy. Without preliminary theoretical basis to justify the choice of a policy, any policy action is hazardous and could prove to be expensive and inappropriate because it may generate undesired effects.

Policies improve the food situation of households offer an abundant literature. This literature is mainly dominated by the controversy as concerns the choice of the suitable channel between the price elasticity and income channel of food expenditure and the price elasticity and consumption income of the consumption of calories in the policies of improvement of the nutritional level of the households. The populations vulnerable to the food disasters are more often from the poor classes, with weak real power. The policies based on the increase of the incomes of households for an improvement of their nutritional level do not always have obvious positive effects. They can cause a displacement of the quantity preferences of calories towards goods of luxury with weak nutritional contribution (tobacco, tea...) or towards transport, the leisure, etc. This case is characterised by a low income elasticity of calories, a minimum of improvement of the nutritional state requiring enormous transfers of income. Berhman \& Deolalikar (1987) confirms this with data of the south of India, finding that elasticities are never significantly different from zero. They establish thereafter that the increase in the incomes does not have any positive impact on the nutritional level of households (Berhman \& Deolalikar, 1990). This idea was not accepted by Strauss \& Thomas (1990) and Subramanian \& Deaton (1992).

Strauss and Thomas (1990), with data on Brazil, estimate the income elasticity of calories in the interval from 0.25 to 0.3 . Subramanian \& Deaton (1992) estimate the income elasticity of calories in the interval from 0.3 to 
0.5 for rural Maharastra. For these researchers the income elasticity of calories is lower than the income elasticity of food expenditure. They therefore choose the channel of income elasticity of food expenditure. Earlier Knudsen \& Scandizzo (1982) had estimated the income elasticity of calories for five underdeveloped countries and located them in the interval from 0.53 to 0.74 for the poorest quartile. For these authors, the suitable channel is the channel of income elasticity of calories.

The aim of this study is to locate Cameroonian case in the controversy and to propose an efficient channel of the transfer of the effects of the policy actions in the fight against food insecurity. This channel will arise from a comparative empirical evaluation of the channel of income elasticity of food expenditure and that of income elasticity of the calories consumed. The choice of a given channel must be compatible with the objectives of improvement of the social conditions of the households (education, health).

\section{Methodology}

The estimation of price elasticities is useful in the evaluation of the actions relating to the prices of the foodstuffs of great consumption by the poor. This estimate is done by adopting the technique of Deaton (1989 et 1990) with an application of the method of Frisch(1959). It is assumed that the flexibility of the currency (Note 1) for Cameroon at a low level of real income is equal to -4 .

The responsiveness to prices of the amount of calories consumed calories can then be measured by the coefficient $E_{c i}$ as:

$$
E_{c i}=\frac{\partial C / C}{\partial P_{i} / P_{i}}=\frac{\sum_{j} a_{c i} q_{j} E_{j i}}{\sum_{j} a_{c j} q_{j}}
$$

In the same way, the responsiveness to prices of the food expenditures will be measured by:

$$
\begin{aligned}
& E_{i i}=\frac{\partial Q_{i} / Q_{i}}{\partial P_{i} / P_{i}}=\frac{1}{\omega} n_{i}\left(1-w_{i} n_{i}\right)-w_{i} n_{i} \\
& E_{i j}=\frac{\partial Q_{i} / Q_{i}}{\partial P_{j} / P_{j}}=-\frac{w_{i}}{\omega} n_{i} n_{j}-w_{j} n_{j}, i \neq j
\end{aligned}
$$

One can also measure the responsiveness of the consumed amount of calories to the annual income of the households by the coefficient $n_{c y}$ :

$$
n_{c y}=\frac{\partial C / C}{\partial Y / Y}=\frac{\sum_{j} a_{c j} q_{j} n_{j}}{\sum_{j} a_{c j} q_{j}}
$$

Once the various parameters are estimated, one can have an idea of the transmission mechanism of the effects of food policies. A variation of the relative prices of the various goods produces an effect on the real income measured and an effect on the demand of a given good, $i$ measured by:

$$
\frac{\Delta Y}{Y}=-\sum_{i} w_{i} \frac{\Delta P_{i}}{P_{i}} \quad \frac{\Delta q_{i}}{q_{i}}=\sum_{j} E_{i j} \frac{\Delta P_{j}}{P_{j}}, i=1,2 \ldots n .
$$

The income elasticities will be evaluated using a log-log specification of the expenditure, income and consumed calories of households.

Data from the 1996 ECAM survey will be used for this purpose. In view of taking into account of the social sector in the implementation of the policies of the fight against food insecurity, the policies considered to be better will have positive effects on education and health mainly.

Parameters of demand for a certain segment of the population will thus be estimated. They are the vulnerable segment, food situation is generally considered by the actions of policy. They can be also the rich segment, which generally direct their preferences towards products with very weak nutritional contribution or towards leisure goods. The nonvulnerable segment in general can absorb all the effects of the actions of the authorities in the event of food disaster. The estimation of the parameters of these particular segments allows the control of the 
behavior of the households towards policies of assistance and the drain of the positive effects towards the target segments.

The Slutsky, Engel, Cournot and Euler relations (Note 2) should be satisfied. The Slutsky relation highlights the substitution and income effects. Euler's relation makes it possible to remove the effect of monetary illusion. The relations of Engel and Cournot make it possible to gauge the price and income elasticities.

\section{Results}

The examination of the graph and the detection of the correlations, the estimation of the parameters and the description of the transmission channels of the effects of the policies constitute an important knowledge for a development of effective policies of intervention situations of food insecurity.

\subsection{Graphical Examination and Detection of the Correlations}

The graphical examination shows that the consumption of calories and food expenditure of the households present a similar evolution in the form of a hyperbola. They present a positive correlation where consumption of calories is explained primarily by food expenditure (Note 3) $(\mathrm{F}=83.22$ and $\mathrm{DW}=3.35)$. These quantities can be brought back to the level of the adult equivalent and the level of expenditure per capita. The food expenditure by adult equivalent and per head respectively explain consumption of energy per adult and per head (Note 4) (with respectively $\mathrm{F}=24.85$ and $\mathrm{DW}=3.41$, and $\mathrm{F}=14.53$ and $\mathrm{DW}=3.40$ ). A graphical examination (Note 5) of the curves of evolution of consumption of calories per capita and adult equivalent reveals a "W"-shape. This is explained by the taking into account of the differences in ages and sizes of the households. (Note 6) It is also explained by the consumption of the goods for high nutritional purposes such as proteins, fish, eggs and jams with great concentration of the vitamins for the rich households. It is finally explained by the great importance of the subsistence farming of food products such as cereals with great energy contents by the poor deciles, mainly peasants. An examination of the graph also reveals a similar evolution between food expenditure and incomes of households. A correlation test shows that food expenditure is explained annual income and the constant term (Note 7) $(\mathrm{F}=64.16$ and $\mathrm{DW}=2.35)$. Because of the predominance of the constant term in the explanation of the food expenditure by the annual incomes of the households (Note 8), it is established a consequent relation between consumption of calories and annual income. In fact the consumed quantities of calories are more explained by the constant term $(\mathrm{t}=6.56)$ than by the annual income $(\mathrm{t}=4.52)$ for a regression a good fit (Note 9) $(\mathrm{F}=20.39$ and $\mathrm{DW}=2.92)$. The regressions of consumption of calories per capita and adult equivalent on the annual income per capita and adult equivalent (Note 10) are not all significant, the great importance of subsistence farming of the first three poorest deciles and peasant majority being the cause.

\subsection{Nutritional State and Basic Social Needs}

The graphical examination reveals that the expenditure on education and health by no means follows the incomes of households and their standard of living and, as a whole, they are characterized by very low levels $(0$, $1 \%$ and $4,7 \%$ of the total of the household expenses respectively for education and health).

The first decile invests less than a tenth, fifteenth, and hundredth of its leisure, personal care and food expenditures respectively for education while the rest of the population spends half of its expenditure on personal care. The per capita expenditure on education and health also evolve as a positive function of income although the fact that this evolution is in saw-tooth is likely to make adjustments with negative slopes possible for certain standards of living.

As a whole, food expenditure and expenditure on housing are essential in household expenses, households which assign a negligible part of their real incomes to education and the leisure. These two expenditures are the least costly and do not have a priority in the household budget. (Note 11)

\subsection{The Controversy of the Choice of the Optimal Channel: the Cameroonian Case}

The estimates of the income elasticity of calories in the case of the northern regions of Cameroon locate them in the interval from 0.21 to 1.54 . In spite of the strong variation of these coefficients in the interval, they are in line with a number of authors for whom these elasticities are significant, the demarcation being total with Berhman \& Deolalikar (1987). The fact that for several deciles, the income elasticity of calories are higher than the income elasticity of food expenditure which ranges between 0.39 and 0.59 , one is in perfect agreement with Knudsen \& Scandizzo (1982). In fact the majority of the deciles are ready to improve their food level, especially by directing their food budget towards the consumption of goods with high nutritional values.

Garcia, Pinstrup \& Andersen (1987) establishes that the calorific consumption of children in the Philippines is positively related to the price of rice while that of the household is negatively related to it. 
For the case of Cameroon, the consumption of calories is negatively connected to the price of food. Our estimates (Note 12) give an elasticity of consumption of calories to food price equal to -1.03 . They also give a price elasticity of food expenditure equal to -0.83 . A fall food price causes a less than proportional increase in food expenditure.

\section{Discussions}

\subsection{Experimentation (Note 13) of Single Policy Actions and Implications}

Policy actions in order to be effective must be based on appropriate channels with high transmission effect. An experimentation of policies is required in order to choose the best channels.

The detection of an effective channel of transmission of the effects of policy actions aiming at the improvement of the food state of the households requires a certain number of experiments relating to the modifications of the variables or parameters of demand. This experimentation must be carried out in the strict respect of the situations of the households in the basic social sectors such as education and the health which must in addition be raised.

A first series of experiments relates to the individual actions on real incomes and the food expenditure of the target households.

The modification of real income through a fall in the food price of $50 \%$ leads to an increase in the demand of foodstuffs of $42 \%$. This policy leads to negative effects on education and health with a respective fall of $87 \%$ and $28 \%$.

When the increase in the real income is carried out by an increase in money-income, the demand of foodstuffs increase by $122 \%$, with a strong degradation of the situations in the education and the health of $400 \%$ and $131 \%$ respectively! (Note 14) The policy based of food subsidy consists of a financing of the food deficit of the vulnerable households or disaster victims. The advantage of this tool for redistribution is that it makes it possible to channel the positive effects of the policies towards the target class. In fact, a subsidy on food can be compared to a reduction of the food price.

\subsection{Experimentations of Combinations of Policy Measures and Implications}

The second series of experiments consists of a combination of policy measures, making it possible to suppress the non desireable effects of the individual actions on the variables while ensuring the nutritional wellbeing of the vulnerable ones.

Consider an increase in the incomes of households of $100 \%$ (Note 15) and suppose increases in the unit costs of housing, transport, education and health of $50 \%, 50 \%, 200 \%$ and $80 \%$ respectively. The effects are a fall in food expenditure of $12.5 \%$ and an improvement of the expenditure of education and health of $241.5 \%$ and $40.4 \%$.

A new combination of variations of the prices of $50 \%, 60 \%, 300 \%$ and $150 \%$ of housing, transport, education and health respectively improve the education and health expenditures by of $360 \%$ and $60.4 \%$.

Let us suppose a subsidy of $50 \%$ on the food price and the falls of $25 \%$ of the unit costs of housing, transport and clothing. These measurements generate negative effects on education and health. These effects are made positive by increases of the costs of education and health of $100 \%$ and $50 \%$ !

Direct actions on food prices have a fast impact on the level of food consumption of the household. However, combinations of policy measures show that the fall of the food prices exerts negative effects on the basic social sector (education and health). Rendering these effects positive or cancelling them is very expensive. The food subsidy instrument produces effects of comparable nature and of the same intensity as the reduction of the food price with; however, an improvement of the situations in the basic social sector by the created revenue effect. These food subsidies must relate to foodstuffs of exclusive consumption of the poor classes and must consist of identifiable vouchers with an aim of channeling the effects of the policy. The policy based on food subsidy is a valid alternative to the policy of improvement of the money-incomes of the poor whose channel of calories elasticity has proven its effectiveness. 


\section{Conclusion}

This study treated questions related to the phenomenon of food insecurity in the northern provinces of Cameroon. The aim was to locate the Cameroonian case in the income elasticity of food expenditures and income elasticity of consumed calories controversy, to experiment the policies of the fight against the food insecurity and how they interact with those aiming at suppressing the undesirable effects on the basic social sector.

The study locates the income elasticity of food expenditure in the interval $(0.21,1.54)$ for the poor decile considered as target population. The income elasticity of calories consumed as for them lie between 0.39 and 0.59 for the poor decile and several other deciles. The channel of income elasticity of food expenditure, in spite of the strong variation of these elasticities, constitutes the best alternative. However, the choice of a channel will take account of its effects on the social sector, the northern regions being characterized by very significant deficits education health (deficits in terms of cover and the conditions of access).

\section{References}

Alim, B. (2001). Les Politiques Quantitatives de Redistribution: Un Essai d'Application dans la Lutte contre l'Insécurité Alimentaire. Mémoire du D.E.A, Université de Yaoundé II.

Berhman, J., \& Deolalikar, A. (1987). Will Developing Country Nutrition improve with Income? A case for Rural South India. Journal of Political Economy, 95, 492-507. http://dx.doi.org/10.1086/261469

Berhman, J., \& Deolalikar, A. (1990). The Intrahousehold Demand for Nutrients in Rural South India: Individual Estimates, fixed Effects, and Permanent Income, Journal of Human Resources, 25, 665-95. http://dx.doi.org/10.2307/145671

Deaton, A. (1989). Household Survey Data and Pricing Policies in Developing Countries. World Bank Economic Review, 3, 183-210. http://dx.doi.org/10.1093/wber/3.2.183

Deaton, A. (1990). Price Elasticities for Survey Data: Extensions and Indonesian Results. Journal of Econometrics, 44, 281-309. http://dx.doi.org/10.1016/0304-4076(90)90060-7

Enquête Camerounaise Auprès des Ménages (ECAM96). (1996). Données Brutes, Direction de la Statistique et de la Comptabilité Nationale, MINEFI.

Folbre, N. (1984). Markets Opportunities, Genetic Endowments, and Intrafamily Resource Distribution: Comment. American Economic Review, 74, 518-20.

Frisch, R. (1959). A Complete Scheme for Computing all Direct and Cross Demand Elasticities in a Model with Many Sectors. Econometrica, 27, 177-96. http://dx.doi.org/10.2307/1909441

Garcia, M., \& Pinstrup-Andersen, P. (1987). The Pilot Food Price Food Subsidy Scheme in the Philippines: Its Impact on Income, Food Consumption, and Nutritional Status. Monograph n61, Washington D.C: International Food Policy Research Institute.

Knudsen, O., \& Scandizzo, P. (1982). The Demand for Calories in Developing Countries. American Journal of Agricultural Econometrics, 64, 80-6. http://dx.doi.org/10.2307/1241175

Mc Elroy, M. (1990). The Empirical Content of Nash-bargained Household Behavior. Journal of Human Resources, 25, 559-83. http://dx.doi.org/10.2307/145667

Rosenweig, M., \& Schultz, T. (1982). Markets Opportunities, Genetic Endowments, and IntraFamily Resource Distribution: Child Survival in Rural India. American Economic Review, 72, 803-15.

Senauer, B., Garcia, M. \& Jacinto, E. (1988). Determinant of the Household Allocation of Food in the Rural Philippines. American Journal of Agricultural Economics, 70, 170-80. http://dx.doi.org/10.2307/1241987

Strauss, J., \& Thomas D. (1990). The Shape of the Calories Expenditure Curve, Economic Growth Center. Discussion Papern 595, New Haven: Yale University.

Subramanian, S., \& Deaton, A. (1992). The Demand for Food and Calories: Further Evidence from India. Unpublished Paper: Princeton University Research Program in Developing studies.

Thomas, D. (1990). Intra-household Resource Allocation: An Inferential Approach. Journal of Human Resources, 25, 633-64. http://dx.doi.org/10.2307/145670 


\section{Notes}

Note 1. The technique of Deaton, the method of Frisch and the explanation on the flexibility of the currency can be found in Alim B (2001).

Note 2. These relations are the subject of full illustrations in Alim B (2001).

Note 3. See Régression1.

Note 4. See regression set3.

Note 5. For all that relates to the graphs, refer to the appendix where our principal target variables are presented. Note 6 . The size of the households grows with the level of income, expressing the fact that the members of certain families generally join the households of the rich parents. The number of equivalent adult, him, is stabilized around 04 except for the deciles with high income where it reaches even 08 units.

Note 7. See regression4.

Note 8 . In fact the constant term has student t-value of 6.56 against 4.52 for the variable returned. Food expenditure is still better explained by the constant term when the quantities are brought back at the individual level, $\mathrm{t}=8.95$ against $\mathrm{t}=2.14$.

Note 9. See regression7.

Note 10. See regressions 8 and 9.

Note 11. Appendix: table4.

Note 12. See table3.

Note 13. These experiments relate to the poorest decile of the population. That is in addition the reason which must facilitate the comprehension of the increases at high rates contained in our simulations.

Note 14. Owing to the fact that the households with high incomes generally have as head an uneducated businessman, they invest little in education and health; this leads to a negative correlation between incomes and expenditures in education and health.

Note 15 . An increase of $100 \%$ of the incomes of the vulnerable layers can be estimated sufficient to allow them the food minimum level (2400cal).

\section{Annexes}

1. Graphics
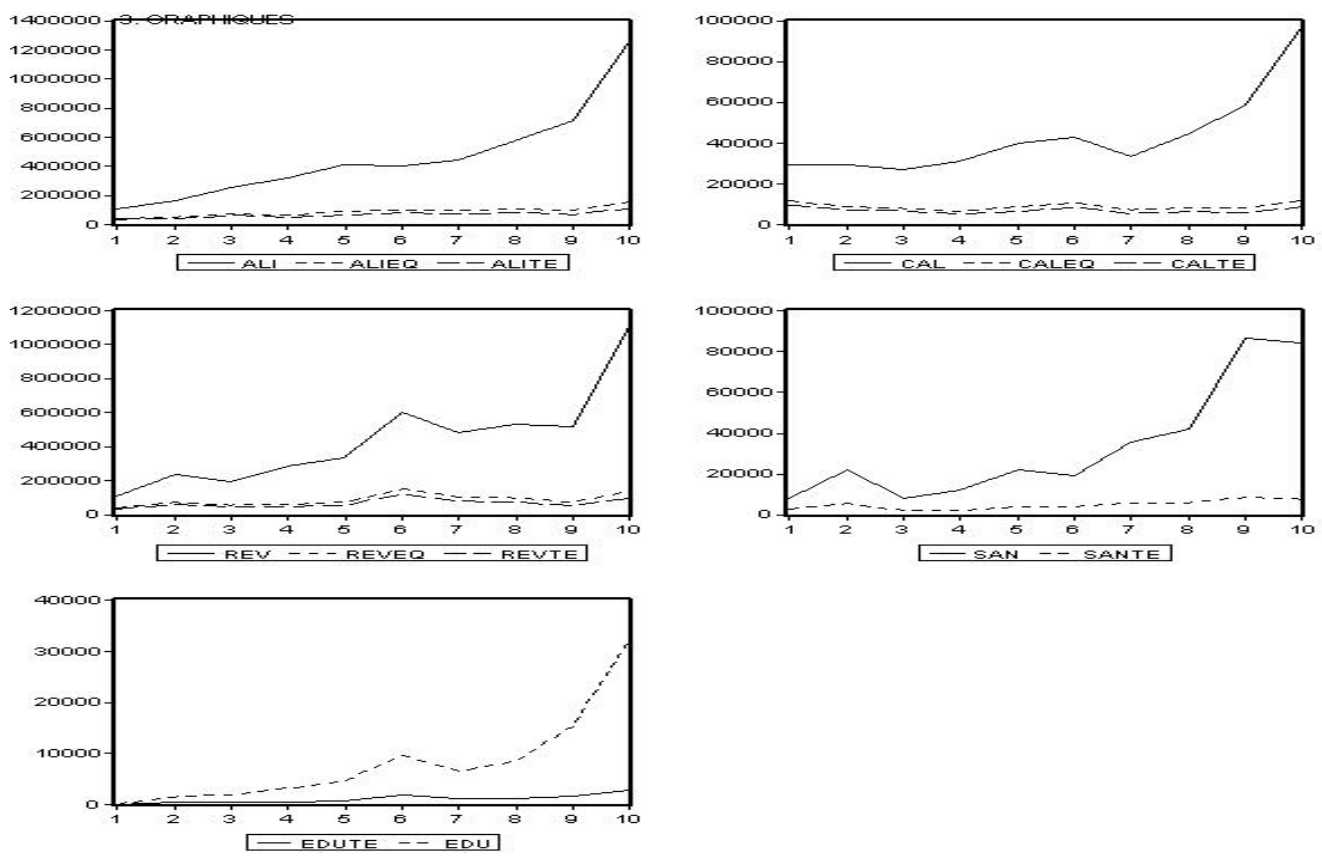
2. Our estimates

Table 1. Budget shares of household expenditure in the first decile

\begin{tabular}{lccccccccc}
\hline EXPENDITURE ITEMS & ALI & LOGE & TRA & EDU & SAN & HAB & MAI & SOP & LOI \\
\hline BUDGET SHARES & 0.623 & 0.147 & 0.012 & 0.001 & 0.047 & 0.093 & 0.060 & 0.011 & 0.008
\end{tabular}

Table 2. Calibrated income elasticities of the household expenditures of the first decile

\begin{tabular}{lcccccccccc}
\hline $\begin{array}{l}\text { POSTES } \\
\text { EXPENDITURES }\end{array}$ & OF & ALI & LOGE & TRA & EDU & SAN & HAB & MAI & SOP & LOI \\
\hline \multirow{2}{*}{ INCOME ELASTICITIES } & & 1.22 & 1.47 & 1.84 & -4.00 & -1.31 & 1.31 & -1.22 & 1.31 & 0.16 \\
\hline
\end{tabular}

Table 3. Calibrated price elasticities of the household expenditures of the first decile

\begin{tabular}{lccccccccc}
\hline $\begin{array}{l}\text { POSTES } \\
\text { PRICES }\end{array}$ & ALI & LOGE & TRA & EDU & SAN & HAB & MAI & SOP & LOI \\
\hline $\mathrm{P}_{\text {ALI }}$ & -0.833 & -0.113 & -0.008 & -0.002 & -0.076 & -0.076 & -0.096 & -0.009 & -0.009 \\
$\mathrm{P}_{\text {LOGE }}$ & -0.636 & -0.504 & -0.010 & -0.019 & -0.092 & -0.092 & -0.115 & -0.011 & -0.011 \\
$\mathrm{P}_{\text {TRA }}$ & -0.797 & -0.171 & -0.472 & -0.004 & -0.115 & -0.227 & -0.144 & -0.014 & -0.014 \\
$\mathrm{P}_{\text {EDU }}$ & 1.732 & 0.372 & 0.026 & 1.008 & 0.250 & 0.250 & 0.313 & 0.030 & 0.031 \\
$\mathrm{P}_{\mathrm{SAN}}$ & 0.567 & 0.134 & 0.008 & 0.003 & 0.409 & 0.082 & 0.103 & 0.010 & 0.010 \\
$\mathrm{P}_{\text {HAB }}$ & -0.567 & -0.122 & -0.008 & -0.003 & -0.082 & -0.409 & -0.103 & -0.010 & -0.010 \\
$\mathrm{P}_{\text {MAI }}$ & 0.528 & 0.113 & 0.008 & 0.002 & 0.076 & 0.076 & 0.401 & 0.009 & 0.009 \\
$\mathrm{P}_{\text {SOP }}$ & -0.567 & -0.122 & -0.008 & -0.003 & -0.082 & -0.162 & -0.103 & -0.337 & -0.010 \\
$\mathrm{P}_{\text {LOI }}$ & -0069 & -0.015 & -0.001 & -0.000 & -0.010 & -0.010 & -0.014 & -0.014 & -0.041 \\
\hline
\end{tabular}

Table 4. Budget priority of households when their incomes increase

\begin{tabular}{cccccccccc}
\hline & $\mathbf{1}^{\text {st }}$ & $\mathbf{2}^{\text {nd }}$ & $\mathbf{3}^{\text {rd }}$ & $\mathbf{4}^{\text {th }}$ & $\mathbf{5}^{\text {th }}$ & $\mathbf{6}^{\text {th }}$ & $\mathbf{7}^{\text {th }}$ & $\mathbf{8}^{\text {th }}$ & $\mathbf{9}^{\text {th }}$ \\
\hline $\mathbf{D}_{\mathbf{1}}$ & TRA & LOGE & HAB & SOP & ALI & LOI & MAI & SAN & EDU \\
$\mathbf{D}_{\mathbf{2}}$ & EDU & TRA & SAN & LOGE & SOP & ALI & HAB & MAI & LOI \\
$\mathbf{D}_{\mathbf{3}}$ & SAN & MAI & LOI & LOGE & SOP & EDU & HAB & ALI & TRA \\
$\mathbf{D}_{\mathbf{4}}$ & TRA & LOI & SOP & LOGE & MAI & HAB & ALI & SAN & EDU \\
$\mathbf{D}_{\mathbf{5}}$ & TRA & SOP & SAN & MAI & LOGE & EDU & LOI & HAB & ALI \\
$\mathbf{D}_{\mathbf{6}}$ & EDU & HAB & LOI & SOP & LOGE & MAI & ALI & SAN & TRA \\
$\mathbf{D}_{\mathbf{7}}$ & EDU & ALI & LOGE & MAI & HAB & SOP & TRA & SAN & LOI \\
$\mathbf{D}_{\mathbf{8}}$ & LOI & HAB & MAI & SOP & SAN & LOGE & EDU & ALI & TRA \\
$\mathbf{D}_{\mathbf{9}}$ & ALI & SOP & HAB & LOGE & TRA & MAI & EDU & SAN & LOI \\
$\mathbf{D}_{\mathbf{1 0}}$ & SOP & TRA & EDU & ALI & LOI & HAB & MAI & LOGE & SAN \\
\hline
\end{tabular}




\section{Regressions}

Regression 1

Dependent Variable: CAL

Method: Least Squares

Sample: 110

Included observations: 10

\begin{tabular}{ccccc}
\hline Variable & Coefficient & Std. Error & t-Statistic & Prob. \\
\hline C & -2372.950 & 5269.764 & -0.450295 & 0.6644 \\
ALI & 0.098164 & 0.010760 & 9.122707 & 0.0000 \\
R-squared & 0.912304 & Mean dependent var & 42026.10 & R-squared \\
Adjusted R-squared & 0.901342 & S.D. dependent var & 20345.75 & Adjusted R-squared \\
S.E. of regression & 6390.591 & Akaike info criterion & 20.53990 & S.E. of regression \\
Sum squared resid & $3.27 \mathrm{E}+08$ & Schwarz criterion & 20.60041 & Sum squared resid \\
Log likelihood & -100.6995 & F-statistic & 83.22378 & Log likelihood \\
\hline
\end{tabular}

Regression 2

Dependent Variable: CALEQ

Method: Least Squares

Sample: 110

Included observations: 10

\begin{tabular}{ccccc}
\hline Variable & Coefficient & Std. Error & t-Statistic & Prob. \\
\hline C & -994.9691 & 1953.486 & -0.509330 & 0.6243 \\
ALIEQ & 0.103196 & 0.020699 & 4.985597 & 0.0011 \\
R-squared & 0.756515 & Mean dependent var & 8507.951 & 8507.951 \\
Adjusted R-squared & 0.726079 & S.D. dependent var & 2584.619 & 2584.619 \\
S.E. of regression & 1352.724 & Akaike info criterion & 17.43449 & 17.43449 \\
Sum squared resid & 14638902 & Schwarz criterion & 17.49500 & 17.49500 \\
Log likelihood & -85.17243 & F-statistic & 24.85618 & 24.85618 \\
\hline
\end{tabular}




\section{Regression 3}

Dependent Variable: CALTE

Method: Least Squares

Sample: 110

Included observations: 10

\begin{tabular}{|c|c|c|c|c|}
\hline Variable & Coefficient & Std. Error & t-Statistic & Prob. \\
\hline R-squared & 0.644943 & Mean dependent var & R-squared & 0.6243 \\
\hline Adjusted R-squared & 0.600561 & S.D. dependent var & $\begin{array}{l}\text { Adjusted } \\
\text { R-squared }\end{array}$ & 0.0011 \\
\hline S.E. of regression & 992.5740 & Akaike info criterion & $\begin{array}{c}\text { S.E. of } \\
\text { regression }\end{array}$ & 6054.848 \\
\hline Sum squared resid & 7881625 & Schwarz criterion & $\begin{array}{c}\text { Sum squared } \\
\text { resid }\end{array}$ & 1570.498 \\
\hline Log likelihood & -82.07668 & F-statistic & Log likelihood & 16.81534 \\
\hline Durbin-Watson stat & 3.400681 & Prob(F-statistic) & $\begin{array}{c}\text { Durbin-Watson } \\
\text { stat }\end{array}$ & 16.87585 \\
\hline R-squared & 0.644943 & Mean dependent var & R-squared & 14.53157 \\
\hline
\end{tabular}

Regression 4

Dependent Variable: ALI

Method: Least Squares

Sample: 110

Included observations: 10

\begin{tabular}{ccccc}
\hline Variable & Coefficient & Std. Error & t-Statistic & Prob. \\
\hline C & 319205.7 & 27655.83 & 11.54208 & 0.0000 \\
REV & 0.313835 & 0.039180 & 8.010055 & 0.0000 \\
R-squared & 0.889137 & Mean dependent var & 452292.9 & 452292.9 \\
Adjusted R-squared & 0.875279 & S.D. dependent var & 197965.5 & 197965.5 \\
S.E. of regression & 69913.26 & Akaike info criterion & 25.32475 & 25.32475 \\
Sum squared resid & $3.91 \mathrm{E}+10$ & Schwarz criterion & 25.38527 & 25.38527 \\
Log likelihood & -124.6238 & F-statistic & 64.16098 & 64.16098 \\
\hline
\end{tabular}




\section{Regression 5}

Dependent Variable: ALIEQ

Method: Least SquaresS

Sample: 110

Included observations: 10

\begin{tabular}{ccccc}
\hline Variable & Coefficient & Std. Error & t-Statistic & Prob. \\
\hline C & 76787.03 & 6300.044 & 12.18833 & 0.0000 \\
REVEQ & 0.202911 & 0.057511 & 3.528187 & 0.0078 \\
R-squared & 0.608766 & Mean dependent var & 92086.33 & 92086.33 \\
Adjusted R-squared & 0.559861 & S.D. dependent var & 21784.28 & 21784.28 \\
S.E. of regression & 14452.34 & Akaike info criterion & 22.17196 & 22.17196 \\
Sum squared resid & $1.67 \mathrm{E}+09$ & Schwarz criterion & 22.23247 & 22.23247 \\
Log likelihood & -108.8598 & F-statistic & 12.44810 & 12.44810 \\
\hline
\end{tabular}

Regression 6

Dependent Variable: ALITE

Method: Least Squares

Sample: 110

Included observations: 10

\begin{tabular}{ccccc}
\hline Variable & Coefficient & Std. Error & t-Statistic & Prob. \\
\hline C & 56094.14 & 3249.462 & 17.26259 & 0.0000 \\
REVTE & 0.180025 & 0.042422 & 4.243612 & 0.0028 \\
R-squared & 0.692405 & Mean dependent var & 65611.89 & 65611.89 \\
Adjusted R-squared & 0.653956 & S.D. dependent var & 12639.92 & 12639.92 \\
S.E. of regression & 7435.496 & Akaike info criterion & 20.84277 & 20.84277 \\
Sum squared resid & $4.42 \mathrm{E}+08$ & Schwarz criterion & 20.90329 & 20.90329 \\
Log likelihood & -102.2139 & F-statistic & 18.00824 & 18.00824 \\
\hline
\end{tabular}

Regression 7

Dependent Variable: CAL

Method: Least Squares

Sample: 110

Included observations: 10

\begin{tabular}{ccccc}
\hline Variable & Coefficient & Std. Error & t-Statistic & Prob. \\
\hline C & 29733.16 & 4531.640 & 6.561237 & 0.0002 \\
REV & 0.028988 & 0.006420 & 4.515299 & 0.0020 \\
R-squared & 0.718190 & Mean dependent var & 42026.10 & 42026.10 \\
Adjusted R-squared & 0.682964 & S.D. dependent var & 20345.75 & 20345.75 \\
S.E. of regression & 11455.87 & Akaike info criterion & 21.70725 & 21.70725 \\
Sum squared resid & $1.05 \mathrm{E}+09$ & Schwarz criterion & 21.76777 & 21.76777 \\
Log likelihood & -106.5362 & F-statistic & 20.38792 & 20.38792 \\
\hline
\end{tabular}




\section{Regression 8}

Dependent Variable: CALEQ

Method: Least Squares

Sample: 110

Included observations: 10

\begin{tabular}{ccccc}
\hline Variable & Coefficient & Std. Error & t-Statistic & Prob. \\
\hline C & 7074.955 & 941.4264 & 7.515145 & 0.0001 \\
REVEQ & 0.019006 & 0.008594 & 2.211476 & 0.0579 \\
R-squared & 0.379394 & Mean dependent var & 8507.951 & 8507.951 \\
Adjusted R-squared & 0.301818 & S.D. dependent var & 2584.619 & 2584.619 \\
S.E. of regression & 2159.637 & Akaike info criterion & 18.37012 & 18.37012 \\
Sum squared resid & 37312262 & Schwarz criterion & 18.43064 & 18.43064 \\
Log likelihood & -89.85062 & F-statistic & 4.890626 & 4.890626 \\
\hline
\end{tabular}

Regression 9

Dependent Variable: CALTE

Method: Least Squares

Sample: 110

Included observations: 10

\begin{tabular}{ccccc}
\hline Variable & Coefficient & Std. Error & t-Statistic & Prob. \\
\hline C & 5198.261 & 580.8816 & 8.948916 & 0.0000 \\
REVTE & 0.016202 & 0.007584 & 2.136468 & 0.0651 \\
R-squared & 0.363285 & Mean dependent var & 6054.848 & 6054.848 \\
Adjusted R-squared & 0.283696 & S.D. dependent var & 1570.498 & 1570.498 \\
S.E. of regression & 1329.187 & Akaike info criterion & 17.39938 & 17.39938 \\
Sum squared resid & 14133907 & Schwarz criterion & 17.45990 & 17.45990 \\
Log likelihood & -84.99690 & F-statistic & 4.564496 & 4.564496 \\
\hline
\end{tabular}

